\title{
Overcoming the expectation gap: ICTY's positive legacy. The Bosnian case
}

\author{
Lara J. Nettelfield (2010) Courting Democracy in Bosnia and Herzegovina. The
} Hague Tribunal's Impact in a Postwar State New York: Cambridge University Press.

\section{What might Bosnia and Herzegovina look like if the ICTY had never existed?}

The arrest and subsequent extradition to The Hague for trial of the wartime Bosnian Serb general, Ratko Mladić (on 26 May 2011), and of the Croatian Serb third president of the self-proclaimed Republic of Serbian Krajina, Goran Hadžič (on 20 July 2011), ends the cat-and-mouse game the international community has been playing for over a decade with Karadžić and Mladić. This represents a significant achievement for the 1993-established International Criminal Tribunal for the former Yugoslavia (ICTY) in its struggle for state co-operation. ${ }^{1}$

In the absence of enforcement powers, the strategy of the chief prosecutors and their fierce determination have been pivotal and successful in moving states - in this particular case, Serbia - to co-operate and deliver the last two remaining fugitives out of the 161 individuals indicted by the Tribunal. Their respective trials will complete the picture of the crimes committed in the Balkans in the 1990s and carry an impact for the ICTY's completion strategy, introduced in 2003 - even if the late arrests and the obvious complexity of most of the cases are introducing unavoidable delays. ${ }^{2}$ This may also foster a more positive representation of the Tribunal, which is more often criticised - too weak, too expensive, too bureaucratic and selective ${ }^{3}$-than praised.

As a matter of fact, transnational justice does not stop at the door of the courts and the ICTY's broader tasks - contributing to the restoration and maintenance of peace, ending impunity and promoting reconciliation - may be certainly perceived as extralegal, but the essential goals of course extend well beyond the lifetime of the Tribunal and require obviously more than judicial intervention. The necessity for Yugoslav successor states to co-operate fully with the Tribunal - also an accession condition of the European Union (EU) - goes indeed beyond compliance. 'Compliance' is about a state submitting to the orders of the Tribunal whereas 'co-operation' is about a state's em-

1 On this issue, see Victor Peskin (2008) International Justice in Rwanda and the Balkans Cambridge and New York: Cambridge University Press; and my book reviews: Christophe Solioz (2008) 'Justice in between Resistance and Co-operation' South-East Europe Review 11(1): 137-141; and Christophe Solioz (2008) 'Breaking the Circle of Impunity' Südosteuropa Mitteilungen 18(5-6): 44-7.

2 The ICTY President and Prosecutor submitted to the UN Security Council on 18 May 2011 their most recent Completion Strategy Report. All the reports are available at: http://www.icty.org/ tabs/14/2.

3 For a comprehensive and balanced approach developed in a broader perspective, see Cherif Bassiouni (Ed.) (2010) The Pursuit of International Criminal Justice: A World Study on Conflict, Victimization and Post-Conflict Justice Cambridge and Antwerpen: Intersentia. 
brace of the norms of international justice as well as a strengthening of the rule of law which requests local ownership and deep societal changes in the direction of international justice. Such long-term objectives - encompassing the complex relations between law and changes in society and politics - raise the question of the social and political impact of the ICTY in post-war transitional democracies. This is precisely the issue examined in Lara J. Nettelfield's must-read book: Courting Democracy in Bosnia and Herzegovina.

Many scholars have drawn pessimistic conclusions on the local effects of the ICTY, but not so Nettelfield. Instead of setting an unrealistically high bar for evaluating the potential of international courts in post-conflict environments, the author works out a realistic assessment of the record and impact of the ICTY. This brings Nettelfield to identify that:

The ICTY contributed to positive democratic development inside the country,

playing, notably, a role in:

The creation of new postwar political identities based on the rule of law and participation

and, last but not least, facilitating:

The mobilization of civil society groups that lobbied for accountability, legislative changes and financial redress. (p. 15)

Another lasting effect of the Tribunal is that it challenged extreme versions of nationalist narratives and opened a space in Bosnian society in which the past may be discussed. Despite slow progress and resistances, the norms modelled by the court have been accepted and internalised. In some cases, support was initially only rhetorical but this first change in the rhetoric was already, at this point, contributing a positive spillover effect (see p. 274).

These are some of the major findings resulting from the author's field research (1998-2008) that combines various methodological tools: survey methodology; ethnographic research; oral history technique; and archival work. Nettelfield's law and society approach seeks to measure the transformative potential of international criminal law, taking into consideration the literature on law and society as well as on the anthropology of law. Next to many very stimulating general theoretical and policy thoughts on the role of the international justice institutions, this book - viewing the Tribunal as a tool for social changes, paying attention to how international law is used in an everyday context - examines on the one hand the Tribunal's impact on Bosnia's judicial system through the reappointment of all prosecutors and judges, the creation of a War Crimes Chamber at the Court of Bosnia and Herzegovina, and the search for a strategy to guide prosecutions (Chapter 8); while, on the other hand, focusing on the evolution of the attitudes and representations of various segments of the population towards the Tribunal (chapters discussed below).

The volume first discusses the transition and transitional justice literature (Chapter 2). Against the opinion of those who view the ICTY as a form of 'imperialism' with poor legitimacy in the country, the author reminds the reader that the Socialist Federal Republic of Yugoslavia (SFRY), Bosnia and Herzegovina included, had a legal tradi- 
tion corresponding to the standards of international law. ${ }^{4}$ This is not to say that local judicial capacities were not to be developed. The author mentions that the Tribunal influenced Bosnian judicial reform and the initiation of local trials (see Chapter 8); furthermore, it stimulated the:

Creation of institutional expectations beyond the ICTY's formal capacity, ( $p$. 35)

thereby creating a space for political discussion and participation, favouring the evolution of perceptions and attitudes, and facilitating the growth of democratic institutions (p. 55).

The next section (Chapter 3) delivers a welcome insight into the historical and political context. The war and early post-war years are, in particular, accurately reviewed, providing the reader with a deep understanding of the circumstances in which the ICTY had to work. Chapter 4, discussing extensively the genocide committed in Srebrenica (1995), ${ }^{5}$ analyses the strategies of collective action of the various family associations representing survivors. Nettelfield supplies evidence on how the ICTY's findings and judgments, as well as, interestingly, also its failings, provided - in a climate of denial characterising these post-war years - the arguments that have enabled victims to advance claims of accountability that included not only the perpetrators of war crimes but also the international community - notably the United Nations (UN) and the Dutch government (pp. 114-119). ${ }^{6}$ The author very convincingly demonstrates how international criminal law in action firstly influenced domestic developments in the country; and, secondly, contributed to the fostering - even if this did not properly become a social movement, as argued (p. 101) - of a significant degree of mobilisation aimed at helping citizens' claim their rights not only in The Hague but also within their own state.

Chapter 5 further examines NGO attitudes towards the Court, replicating a panel study published in 2000 by Cibelli and Gubererk - an approach delivering longitudinal quasi-panel data. ${ }^{7}$ The comparison of results clearly provides evidence that, despite knowledge of the ICTY not improving substantially within the country, there was, over time, a change in attitude for the better towards the ICTY in the sense that the level of legitimacy of the Court increased. The author gained the impression that at least some

4 An argument which would have merited further development. See Xavier Bougarel (2009) 'Du code pénal au mémorandum. Les usages du terme génocide dans la Yougoslavie communiste' in Isabelle Delpla and Magali Bessone (Eds.) (2009) Peines de guerre. La justice pénale internationale et l'ex-Yougoslavie Paris: EHESS, pp. 67-84.

5 See the forthcoming book written jointly by Lara J. Nettelfield and Sarah E. Wagner (2012) Srebrenica in the Aftermath of Genocide New York: Cambridge University Press.

6 In July 2011, Hasan Nuhanović - a former UN interpreter for the Dutch peacekeepers who were stationed in Srebrenica in 1995 - won an appeal against the Dutch Government, with the court stating that the Dutch were to blame for handing over his family members to the Bosnian Serb Army. Nuhanović, as well as the family of Dutchbat electrician Rizo Mustafić, focused on the rights of those who had been inside the UN compound and who were handed over to the Bosnian Serb forces, and cited the ICTY's jurisprudence in their filings.

7 Kristen Cibelli and Tamy Guberek (2000) Justice Unknown, Justice Unsatisfied? Bosnian NGOs Speak about the International Criminal Tribunal for the former Yugoslavia Boston: Tufts University. 
of the Court's extra-legal objectives had been fulfilled (pp. 168-170). The media coverage (pp. 157-164) and, more significantly, the Tribunal's outreach programme pragmatically presented and discussed in a critical way (pp. 152-7, 171-3, 207-208)proved to be instrumental in bringing the ICTY closer to targeted groups in that they:

Have led to more favourable attitudes about the court and have tempered unrealistic expectations (p. 282).

They also provided Bosnians with a reliable source of information about the Tribunal - while Bosnian politicians are perceived as manipulating information about the ICTY.

Based on in-depth interviews conducted in Konjic, Chapter 6 discusses the various contrasting narratives of the war, focusing on the case of the Čelebici trial - ICTY's first trial of individuals not of Serb ethnicity. ${ }^{8}$ The Čelebići prison camp, detaining in 1992a few hundred Bosnian Serbs who were subjected to a range of abuses and atrocities, was located in a former facility of the Yugoslav People's Army (JNA) on the territory of the municipality of Konjic (half-way on the road between Sarajevo and Mostar). This case confronted the Bosniak elites with the fact that the Bosnian Army (ARBiH) was also guilty of having committed war crimes - admittedly not on the same scale as the Army of Republika Srpska (VRS). As expected, views of the trial differ as much as views about the motives of the war; attitudes mostly correlate with ethnic attachment but, over time, emotions have been tempered: in particular, Bosnian Serbs have moderated their rhetoric about the Tribunal and Bosniaks express their discontent with the institution more frequently (p. 200). However, Nettelfield also mentions that the ICTY's verdict was able neither to improve so-called 'minority return' - i.e. of Bosnian Serbs - nor to smooth the 'ethnic divide'. Nevertheless, the findings of the Court:

Forced individuals to revise their knowledge, opinions and assumptions about the town's recent past,

and slowly reshaped the political and emotional environment:

In a manner that was, on the whole, positive for the transition process. (p. 209)

Chapter 7 brings a highly interesting insight in a mostly untapped segment of the population, addressing attitudes toward the Tribunal among soldiers in the now-united army (AFBiH). In 2005, Nettelfield conducted a qualitative survey of 463 soldiers (stationed in Sarajevo, Mostar, Tuzla, Banja Luka and Bijeljina) on the following issues:

a) knowledge of the ICTY and humanitarian law

b) changes in the awareness of wartime events as a result of the Court's work

c) attitudes toward the tribunal's extended mandate.

8 The trial commenced on 10 March 1997 and lasted nineteen months. The trial chamber's judgment was announced on 16 November 1998; the appeal judgment on 20 February 2001; the second sentencing judgement on 9 October 2001; and the final appeal judgement on the sentence on 8 April 2003. All the sentences were confirmed. The ICTY case information sheet is available at:

www.icty.org/x/cases/mucic/cis/en/cis_mucic_al_en.pdf. 
The findings - consistent with those presented in Chapter 5 - show that nationalist absolutes have lessened, ${ }^{9}$ that:

Members of all ethnic groups support the ICTY and believe that the court has made contributions toward its extended mandate, (p. 231)

and that there is:

Considerable support for judicial forms of transitional justice. (p. 232)

The author warns against overly-optimistic interpretations, as she does in other sections: attitudes towards the ICTY remain divided along ethnic lines (p. 232); and one survey is not enough to assert the accuracy of the evolution of the representations made (and, thus, further similar investigations should be conducted).

Nettelfield also acknowledges that the globally positive results to which she points throughout her book may well be related to part of her field research being conducted certainly in a difficult environment, but also during a period of positive political development - most of her research was carried out between 2002 and 2005. ${ }^{10}$ Against the background of the almost permanent crisis the country has experienced since $2006,{ }^{11}$ we may expect attitudes to have slid back at least a little.

Nevertheless, the study highlights the concrete outputs that there have been - to mention only a few: two-thirds of those missing have been identified; legal infrastructures have been created; and lasting expectations of justice are now prevalent - all of which tend to anchor the globally-positive variations in attitudes now present in postwar Bosnia. Certainly, civil society groups and elites are using the language of responsibility and accountability more than they did before - this alone would represent a positive legacy. In an uplifting and subtle way, Nettelfield's book thus helps the reader answer the question: 'What might Bosnia and Herzegovina look like if the ICTY had never existed?'

Christophe Solioz is Secretary-General of the Centre for European Integration Strategies (CEIS) in Geneva. He is co-director, with Wolfgang Petritsch, of the series Southeast European Integration Perspectives at the Nomos publishing house and he recently published Retour aux Balkans. Essais d'engagement 1992-2010 Paris: L'Harmattan, 2010.

9 In comparison to a survey conducted in 2000 and 2001, presented in Eric Stover and Harvey M. Weinstein (Eds.) (2006) My Neighbor, My Enemy: Justice and Community in the Aftermath of Mass Atrocity Cambridge: Cambridge University Press.

10 For additional insights regarding this period, see Florian Bieber (2006) Post-War Bosnia Basingstoke: Palgrave; and Christophe Solioz (2005, second edition 2007) Turning Points in Post-War Bosnia Baden-Baden: Nomos.

11 See Wolfgang Petritsch and Christophe Solioz (2011) 'Mladić vor dem Richter, Bosnien vor dem Abgrund' Der Standard Vienna, 1 June, p. 45; an English version has been published as 'What course after the Storm?' openDemocracy 28 May, and available at: http://www.opendemocracy.net/christophe-solioz-wolfgang-petritsch/bosnia-what-course-after-storm. 